\title{
CYCLOTOSAURUS NARASERLUKI, SP. NOV., A NEW LATE TRIASSIC CYCLOTOSAURID (AMPHIBIA, TEMNOSPONDYLI) FROM THE FLEMING FJORD FORMATION OF THE JAMESON LAND BASIN (EAST GREENLAND)
}

\author{
MARCO MARZOLA (D) *,1,2,3,4 OCTÁVIO MATEUS (D ${ }^{1,3}$ NEIL H. SHUBIN $^{5}$ and LARS B. CLEMMENSEN (D) ${ }^{2}$ \\ ${ }^{1}$ GeoBioTec, Departamento de Ciências da Terra, Faculdade de Ciências e Tecnologia, Universidade Nova de Lisboa, Quinta da \\ Torre, 2829-516 Caparica, Portugal,m.marzola@campus.fct.unl.pt; omateus@fct.unl.pt; \\ ${ }^{2}$ Institut for Geovidenskab og Naturforvaltning (IGN), Det Natur-og Biovidenskabelige Fakultet, Københavns Universitet, Øster \\ Voldgade 10, DK-1350 Copenhagen K, Denmark, larsc@ign.ku.dk; \\ ${ }^{3}$ Museu da Lourinhã, Rua João Luís de Moura, 95, 2530-158 Lourinhã, Portugal; \\ ${ }^{4}$ Geocenter Møns Klint, Stengårdsvej 8, DK-4751 Borre, Denmark; \\ ${ }^{5}$ Department of Organismal Biology and Anatomy, University of Chicago, Chicago, Illinois 60637, U.S.A., nshubin@uchicago.edu
}

\begin{abstract}
Cyclotosaurus naraserluki, sp. nov., is a new Late Triassic capitosaurid amphibian from lacustrine deposits in the Fleming Fjord Formation of the Jameson Land Basin in Greenland. It is based on a fairly complete and well-preserved skull associated with two vertebral intercentra. Previously reported as Cyclotosaurus cf. posthumus, C. naraserluki is unique among cyclotosaurs for having the postorbitals embaying the supratemporals posteromedially. The anterior palatal vacuity presents an autapomorphic complete subdivision by a wide medial premaxillary-vomerine bony connection. The parasphenoid projects between the pterygoids and the exoccipitals, preventing a suture between the two, a primitive condition shared with Rhinesuchidae, Eryosuchus, and Kupferzellia. Within Cyclotosaurus, the Greenlandic skull has a distinctive combination of circular choanae (shared with C. ebrachensis, C. posthumus, and C. robustus) and a convex posteromedial margin of the tabulars (also present in C. ebrachensis and C. intermedius). A phylogenetic analysis indicates that C. naraserluki is the sister taxon of the middle Norian C. mordax from southern Germany, with which it shares a pair of premaxillary foramina. Cyclotosaurus is one of the most successful and diverse genera of Late Triassic temnospondyls, with at least eight species reported from middle Carnian to late Norian. Cyclotosaurus naraserluki is the largest amphibian ever reported from Greenland and one of the Late Triassic vertebrates with the highest northern paleolatitude currently known.
\end{abstract}

http://zoobank.org/urn:lsid:zoobank.org:pub:43AAA541-031C-4EE1-B819-4846EBBD1BBB

SUPPLEMENTAL DATA—Supplemental materials are available for this article for free at www.tandfonline.com/UJVP

Citation for this article: Marzola, M., O. Mateus, N. H. Shubin, and L. B. Clemmensen. 2017. Cyclotosaurus naraserluki, sp. nov., a new Late Triassic cyclotosaurid (Amphibia, Temnospondyli) from the Fleming Fjord Formation of the Jameson Land Basin (East Greenland). Journal of Vertebrate Paleontology. DOI: 10.1080/02724634.2017.1303501.

\section{INTRODUCTION}

Late Triassic lake deposits of Norian-?early Rhaetian age of the Fleming Fjord Formation are very well exposed along the margin of the Jameson Land Basin in East Greenland (Clemmensen, 1980a, 1980b) (Fig. 1A-B). These lacustrine deposits have yielded a rich and diverse vertebrate fauna, including most of the main vertebrate groups known from the Late Triassic (Jenkins et al., 1994, 1997, 2001, 2008; Clemmensen et al., 1998, 2016; Gatesy et al., 1999; Milàn et al., 2012; Mateus et al., 2014; Sulej et al., 2014; Hansen et al., 2016; Marzola et al., 2016). The amphibian fauna reported from the Jameson Land Basin includes the plagiosaurid Gerrothorax pulcherrimus Fraas, 1913 (Jenkins et al., 2008), and remains tentatively associated with the capitosaurid Cyclotosaurus Fraas, 1889 (Jenkins et al., 1994; Sulej et al., 2014).

Cyclotosaurus belongs to a family of Late Triassic temnospondyl amphibians, the Cyclotosauridae, sensu Damiani (2001) and Schoch (2008), characterized by a dorsoventrally flat,

\footnotetext{
*Corresponding author.
}

Color versions of one or more of the figures in the article can be found online at www.tandfonline.com/ujvp elongated, parabolic skull, with eye sockets placed in the posterior half of the head, a long, laterally compressed tail, and relatively short limbs (Milner, 1994; Rinehart and Lucas, 2016). Moreover, at least four synapomorphies are known to identify cyclotosaurids: infraorbital canals curving over the lacrimals with a ' $Z$ ' shape, vomerine tusks positioned lateral to the palatal vacuity, a wide parabolic snout, and a vomerine palate as long as wide (Damiani, 2001; Schoch, 2008). Among the largest amphibians to have ever lived (total body length up to $3 \mathrm{~m}$ ), cyclotosaurids were mostly piscivorous, semi-aquatic predators, colonizing freshwater niches, such as rivers and lakes, as well as coastal brackish to marine areas (Milner, 1994; Fortuny et al., 2016; Witzmann et al., 2016).

In this study, we provide the first complete anatomical description and phylogenetic analysis of the capitosaurid skull reported in Jenkins et al. (1994) and associated vertebral intercentra. We support the original assignment of the Greenlandic specimen to the genus Cyclotosaurus based on the undoubted presence of seven of the eight synapomorphies given for this genus in Witzmann et al. (2016). Cyclotosaurus naraserluki is erected as a new species, based on a combination of autapomorphies and associated characters unique among known cyclotosaurids. 
Institutional Abbreviations-BSPG, Bayerische Staatssammlung für Paläontologie und Geologie, Munich, Germany; GCMO, GeoCenter Møns Klint, Borre, Denmark; MB, Museum für Naturkunde Berlin, Berlin, Germany; MGUH, Geological Museum, University of Copenhagen, Copenhagen, Denmark; NMMNH, New Mexico Museum of Natural History, Albuquerque, New Mexico, U.S.A.; SMNS, Staatliches Museum für Naturkunde Stuttgart, Stuttgart, Germany; UCMP, University of California Museum of Paleontology, Berkeley, California, U.S.A.; ZPAL, Institute of Paleobiology, Polish Academy of Sciences, Warsaw, Poland.

Anatomical Abbreviations-AF, adductor fossa; APV, anterior palatal vacuity; $\mathbf{C H}$, choana; ex, exoccipital; ept, ectopterygoid; f, frontal; ij, insula jugalis; IOS, infraorbital sulcus; j, jugal; I, lacrimal; mx, maxilla; n, nasal; NA, naris; OF, otic fenestra; $\mathbf{O R}$, orbit; pal, palatine; par, parietal; pas, parasphenoid; pat, palatine tusk; PF, parietal foramen; PMF, premaxillary foramen; pmx, premaxilla; pof, postfrontal; POS, postorbital sulcus; poo, postorbital; pp, postparietal; pos, postsplenial; PQF, paraquadrate foramen; prf, prefrontal; ps, parasphenoid; pt, pterygoid; $\mathbf{P V}$, palatal vacuity; $\mathbf{q}$, quadrate; $\mathbf{q j}$, quadratojugal; s, squamosal; st, supratemporal; SOS, supraorbital sulcus; t, tabular; to, tooth; $\mathbf{v}$, vomer; vt, vomerine tusk.

\section{MATERIALS AND METHODS}

Cyclotosaurus naraserluki: holotype MGUH.VP 9522 (Figs. 25), a nearly complete skull on exhibit at the GeoCenter of Møns Klint, Denmark. Associated with the skull are two intercentra, MGUH.VP 9523 and MGUH.VP 9524 (Fig. 6). Locality: Macknight Bjerg Quarry, Jameson Land, Greenland (see Jenkins et al., 1994). Horizon and age: Late Triassic (late Norian) of the Fleming Fjord Formation (see Jenkins et al., 1994) (Fig. 1).

\section{Other Taxa Used for Comparison from Personal Observation and the Literature}

The following specimens were analyzed by personal observation of original material: Cyclotosaurus intermedius Sulej and Majer, 2005: ZPAL Ab III 1173 (holotype); C. mordax Fraas, 1913: SMNS 13014 (holotype), 50008, 50059, 50063, and 51102; C. posthumus Fraas, 1913: SMNS 12988 (holotype); C. robustus von Meyer and Plieninger, 1844: SMNS 5775 (holotype), 4139, and 4935; Eocyclotosaurus wellesi Schoch, 2000: UCMP 42841 (holotype), 41343, 41645, 41646, 55466, 123590, 123595, and 125364; E. appetolatus Rinehart et al., 2015: NMMNH P-64166 (holotype), 43126, 63328, 64360, 66832, and 67401; Kupferzellia wildi Schoch, 1997: SMNS 54670 (holotype); and Quasicyclotosaurus campi Schoch, 2000: UCMP 37754 (holotype), 41635, 132022, 172489, 172490, 172491, 172492, and 172493. Photos of C. ebrachensis Kuhn, 1932, BSPG 1931 X 1 (holotype), were kindly provided by Dr. Oliver Rauhut.

From the literature, the following species were analyzed: $C$. buechneri (Witzmann et al., 2016:85, 87, figs. 2-3); C. hemprichi (Kuhn, 1942:tables I-III); Mastodonsaurus cappelensis (Wepfer, 1923); M. giganteus (Schoch, 1999:150, fig. 54); Paracyclotosaurus davidi (Watson, 1956:255, fig. 14); and Procyclotosaurus stantonensis (Paton, 1974:256, fig. 1).

\section{Phylogenetic Analysis}

Cyclotosaurus naraserluki MGUH.VP 9522 was coded in the data set by Witzmann et al. (2016) for a total of 17 taxa and 69 characters (Appendix 1). Character 7 of Witzmann et al. (2016) was reformulated for the present analysis as character 7: Lateral line sulci: weakly impressed and discontinuous (0); continuous and well impressed (1); well impressed laterally and weakly impressed or discontinuous medially (2). State 2 for character 7 was coded for $C$. ebrachensis, C. hemprichi, C. mordax, C. naraserluki, C. posthumus, and C. robustus. We used TNT 1.5-beta, available at www.lillo.org.ar/phylogeny/tnt (Goloboff and Catalano, 2016). We performed an heuristic search, with 1000 replications using Wagner trees as starting trees, followed by tree-bisection-reconnection (TBR), retaining 10 trees per replication.

\section{GEOLOGICAL SETTING}

The Fleming Fjord Formation is exposed in East Greenland at the Jameson Land Basin, between $70^{\circ}$ and $73^{\circ} \mathrm{N}$ (Clemmensen, 1980a, 1980b; Clemmensen et al., 1998, 2016) (Fig. 1). During the Late Triassic, the Jameson Land Basin lay farther to the south, at around $40^{\circ} \mathrm{N}$ (Kent and Clemmensen, 1996; Kent and Tauxe, 2005). The basin was located in a climatic transition zone of the Pangaea continent, between a relatively dry inland of the supercontinent and a more humid peripheral part (Clemmensen et al., 1998, 2016; Kent et al., 2014).

Three members of cyclically bedded lacustrine deposits from the Late Triassic Fleming Fjord Formation, with a thickness of 300-400 m are: the lowermost Edderfugledal Member, the middle Malmros Klint Member, and the uppermost Ørsted Dal Member (Clemmensen, 1980a, 1980b; Clemmensen et al., 1998). The Ørsted Dal Member lies towards the eastern margin of the basin and is composed of a lowermost unit of red mudstones, the Carlsberg Fjord beds, and an uppermost unit of variegated mudstones and light gray dolomitic mudstones, the Tait Bjerg Beds (Jenkins et al., 1994; Clemmensen et al., 2016).

Temnospondyl amphibian remains have been reported from the easternmost part of the basin at the Macknight Bjerg Quarry $\left(71^{\circ} 22^{\prime} \mathrm{N}, 22^{\circ} 33^{\prime} \mathrm{W}\right)$ in the lowermost part of the Carlsberg Fjord beds (Sulej et al., 2014; Clemmensen et al., 2016). The Cyclotosaurus specimen described here originates from this quarry (Jenkins et al., 1994).

The Carlsberg Fjord beds are composed of siliciclastic sediments of mudflat and lake origin. The most common facies are red-brown to purple mudstones, light greenish-gray mud-peloid siltstones with wave ripples, intraformational conglomerate, and light grayish, fine- to medium-grained sandstones with current-formed crossstratification. Numerous Grallator and cf. Brachychirotherium tracks are seen on upper bedding planes of the wave-rippled siltstones, the former attributed to theropod dinosaurs and the latter to stem crocodylians (Clemmensen et al., 2016; Klein et al., 2016).

According to Kent and Clemmensen (1996) and Clemmensen et al. (1998), the Macknight Bjerg Quarry at the base of the Carlsberg Fjord beds of the Ørsted Dal Member has an age of approximately 209 Ma. However, using the stratigraphy of Andrews et al. (2014), the site would be dated around 217 Ma. The age and duration of the Norian has seen considerable work (e.g., Kent and Olsen, 1999; Lucas et al., 2012). According to the International Chronostratigraphic Chart (Cohen et al., 2013; latest version available at www.stratigraphy.org/ICSchart/Chrono stratChart2016-04.pdf), the Norian ranges from $\sim 227$ to $\sim 208.5$ $\mathrm{Ma}$. However, U-Pb dating, biostratigraphy, magnetostratigraphy, and chemostratigraphy analyses place the Norian-Rhaetian boundary at about 205.70 \pm 0.15 Ma (Wotzlaw et al., 2014; Bertinelli et al., 2016). Thus, an age estimate of the quarry site of 209 Ma (Clemmensen et al., 1998) would place it in the late Norian, whereas an age estimate of $217 \mathrm{Ma}$ (Andrews et al., 2014) would give a mid-Norian age.

\section{SYSTEMATIC PALEONTOLOGY}

TEMNOSPONDYLI von Zittel, 1887-1890 STEREOSPONDYLI von Zittel, 1887-1890

CAPITOSAUROIDEA Säve-Söderbergh, 1935

CYCLOTOSAURIDAE Shishkin, 1964 CYCLOTOSAURUS Fraas, 1889

CYCLOTOSAURUS NARASERLUKI, sp. nov. (Figs. 2-6) 


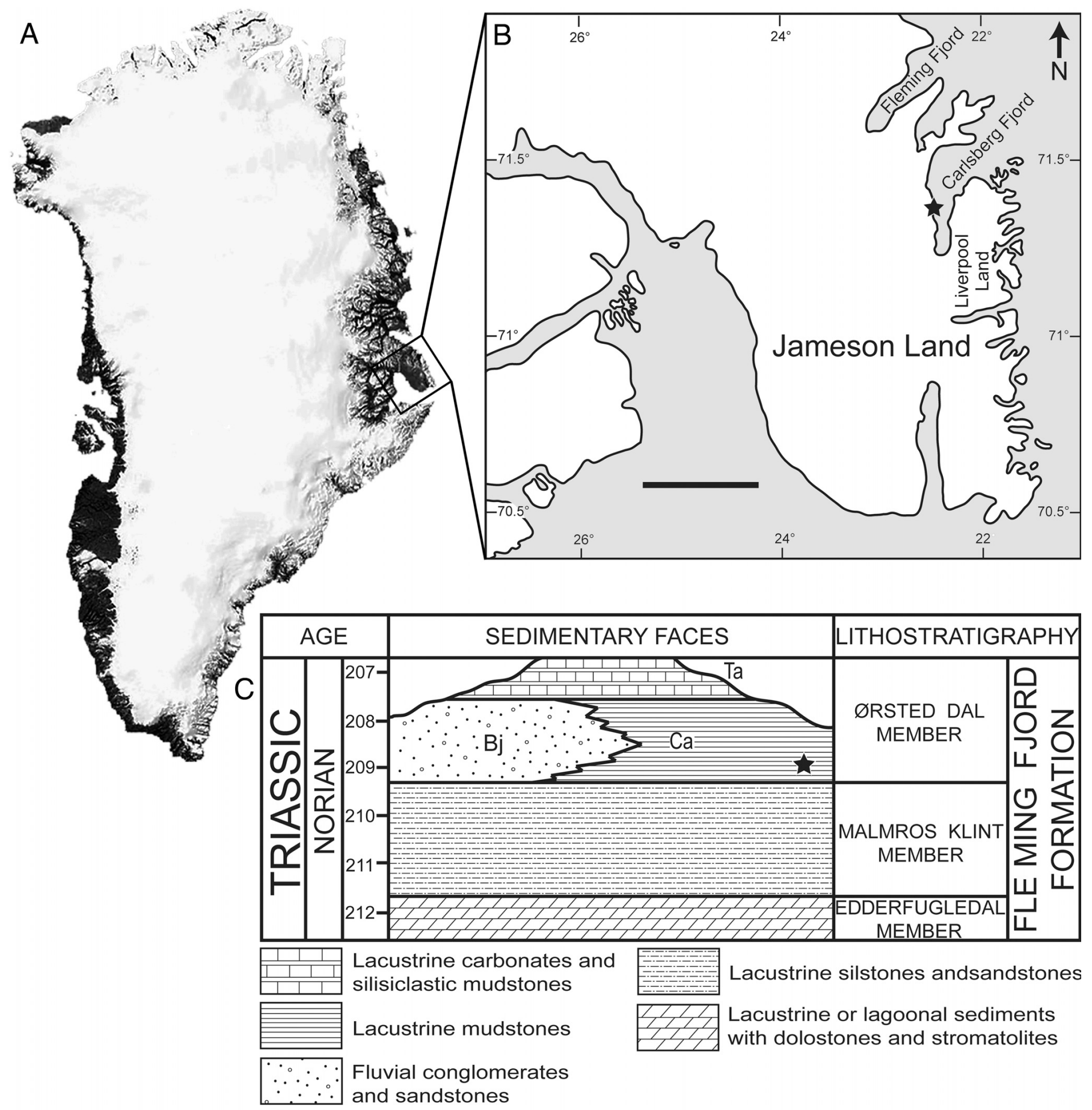

FIGURE 1. A, geographical map of Greenland; $\mathbf{B}$, close-up of Jameson Land and the Liverpool Land area; $\mathbf{C}$, generalized stratigraphic scheme of the Fleming Fjord Formation (after Clemmensen et al., 1998). Stars in $\mathbf{B}$ and $\mathbf{C}$ indicate the site where the holotype of Cyclotosaurus naraserluki was discovered. Abbreviations: Bj, Bjergkronerne beds; Ca, Carlsberg Fjord beds; Ta, Tait Bjerg Beds. Scale bar equals $40 \mathrm{~km}(\mathbf{B})$.

Cyclotosaurus cf. posthumus Fraas, 1913: Jenkins et al., 1994:7-8, figs. 4-5 (original report); Schoch, 2008:202.

Cyclotosaurus, sp. nov.: Schoch and Milner, 2000:156.

Cyclotosaurus posthumus Fraas, 1913: Damiani, 2001:404.

Holotype-MGUH.VP 9522 (previously V-2012-146a, as on the label on the specimen), a mostly complete skull, $56.8 \mathrm{~cm}$ in length along the midline from the tip of the snout to the posterior end of postparietals and with a maximum width of $42.4 \mathrm{~cm}$ (Figs. 2-5; Supplementary Data 1,2).

Associated Material-MGUH.VP 9523 and MGUH.VP 9524 (previously V-2012-268 and V-2012-269, respectively, as on the labels on the specimens), two vertebral intercentra (Fig. 6).

Type Locality-The type specimens were collected during the 1989 expedition to Macknight Bjerg Quarry $\left(71^{\circ} 22.30^{\prime} \mathrm{N}\right.$, $22^{\circ} 33.14^{\prime} \mathrm{W}$ ), at Jameson Land, East Greenland (Fig. 1). 

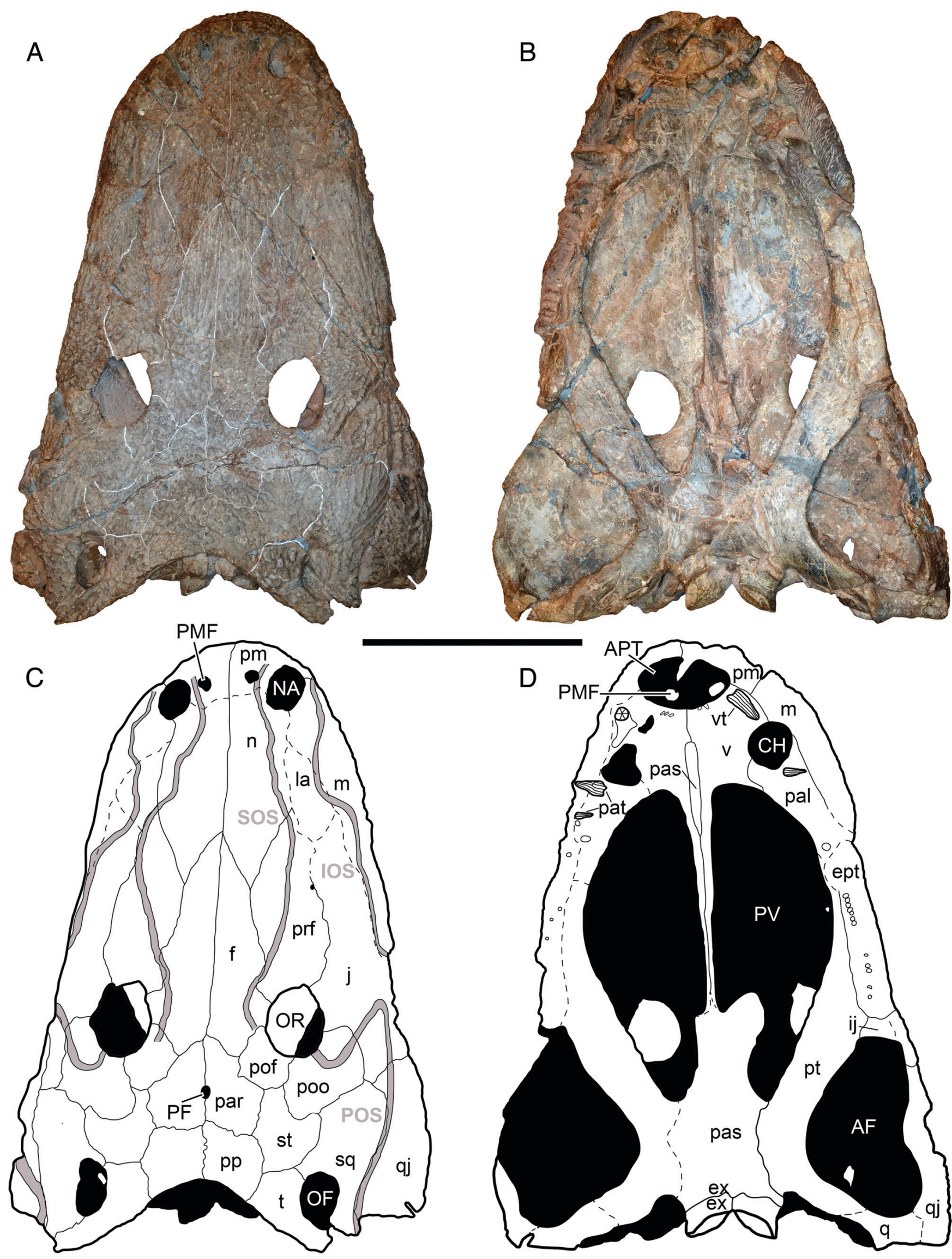

FIGURE 2. The holotype specimen of Cyclotosaurus naraserluki, MGUH.VP 9522. A, C, photograph and interpretative drawing of dorsal view; $\mathbf{B}$, D, photograph and interpretative drawing of ventral view. Scale bar equals $20 \mathrm{~cm}$. 
FIGURE 3. Artwork of the dorsal view of the holotype specimen of Cyclotosaurus naraserluki, MGUH.VP 9522, by Ana Luz (Museu da Lourinhã).

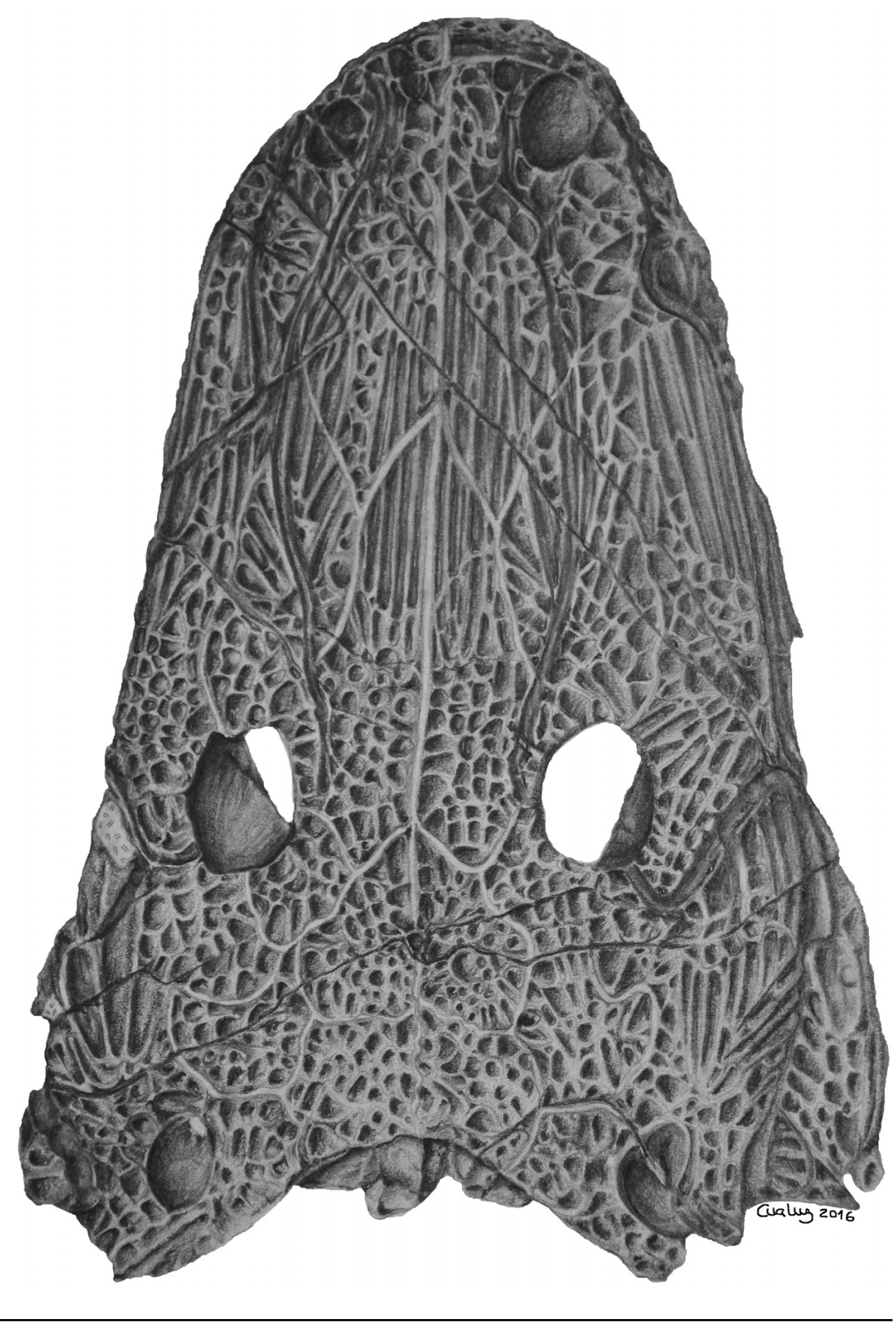

Type Horizon-Late Triassic Carlsberg Fjord beds (Ørsted Dal Member) of the Fleming Fjord Formation (Fig. 1).

Etymology-The specific name is after 'naraserluk,' Greenlandic for 'amphibian, salamander.'

Diagnosis-Cyclotosaurus naserluki has the following autapomorphies among other Cyclotosaurus species: (1) the postorbitals notching posteromedially in the supratemporals; (2) the parasphenoid projecting between the pterygoids and the exoccipitals, thereby preventing a pterygoid-exoccipital suture; and (3) the anterior palatal vacuity is subdivided by a wide medial connection of the premaxillae and the vomers. Moreover, C. naraserluki has the following unique combination of characters among Cyclotosaurus: (1) a pair of premaxillary foramina for accommodating mandibular tusks (shared with C. mordax, see
Fig. 4); (2) a posteromedial convex margin of the tabulars (shared with $C$. ebrachensis and $C$. intermedius, doubtfully with $C$. mordax); and (3) a circular choanal outline (shared with $C$. ebrachensis, C. posthumus, and C. robustus).

\section{DESCRIPTION}

General Aspect and Dermal Bone Ornaments-The entire skull MGUH.VP 9522 (Figs. 2-5; Supplementary Data 1,2) is very well preserved. The skull outline is parabolic, with a widely parabolic snout and convex lateral margin of the postotic region. The only appreciable missing part is the posterior contact of the right tabular and squamosal, which leaves the right otic fenestra open posteriorly. Some sutures and contacts between bones, 

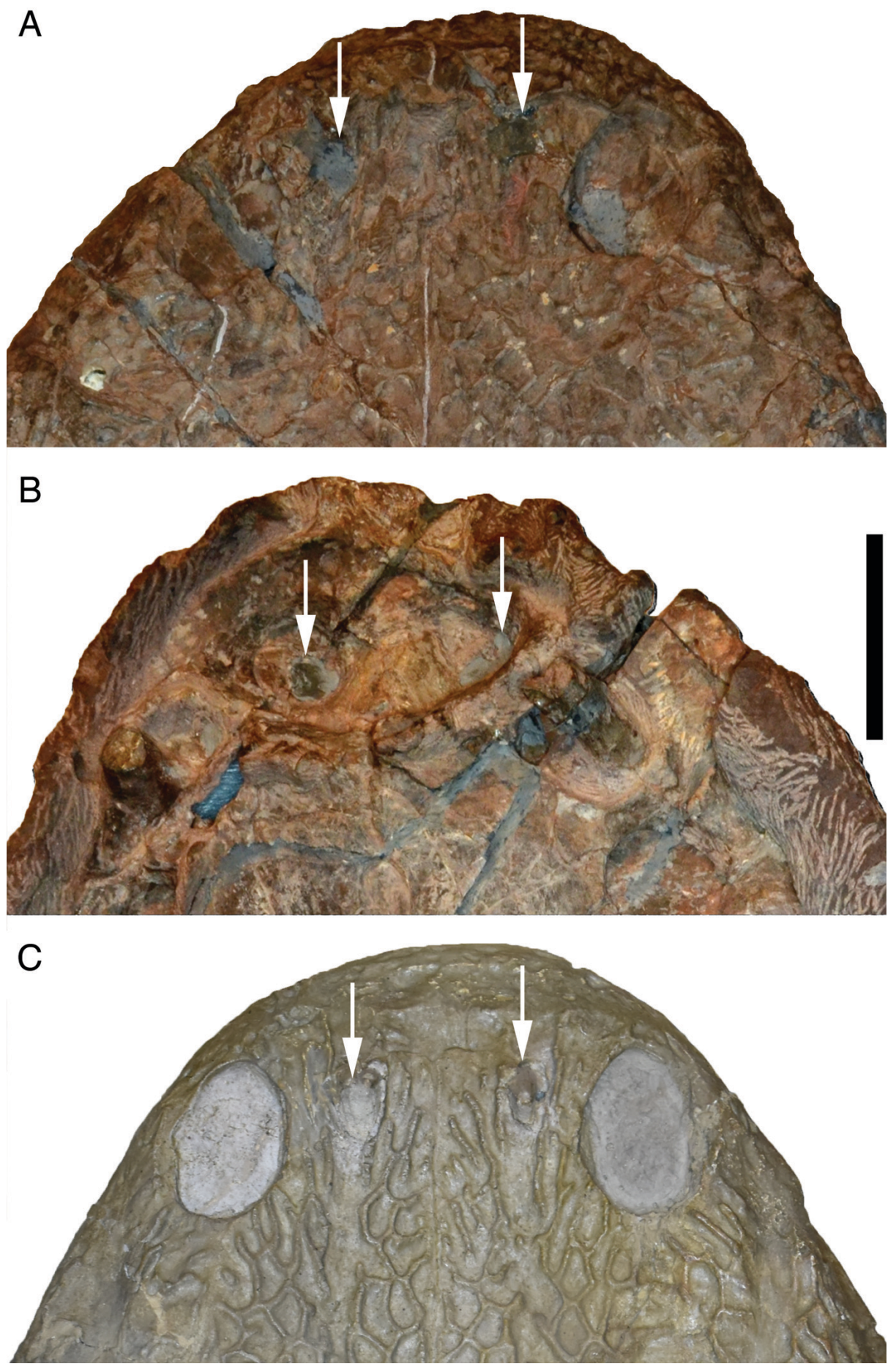

FIGURE 4. Close-up views of the premaxillary foramina (highlighted by white arrows) in cyclotosaurids. A, B, dorsal and ventral views of the holotype of Cyclotosaurus naraserluki, MGUH.VP 9522; C, holotype of Cyclotosaurus mordax, SMNS 13014. Scale bar equals $5 \mathrm{~cm}$. especially from the posterior part of the skull, are not visible due to lack of preparation and sediment still present on the specimen. A slight deformation seems to affect the entire left half of the skull. The bone sutures are more evident in the posterior half of the skull, fading almost to complete fusion anteriorly. Skull length is $56.8 \mathrm{~cm}$, as measured along the midline suture, from the tip of the snout to the posterior end of the postparietals. The maximum width is $42.4 \mathrm{~cm}$, measured at the maximum distance between the lateral margins of the quadratojugals.

Cyclotosaurus naraserluki presents the typical dorsal ornamentation of temnospondyl skulls. Subcircular to subpentagonal pits and a reticular pattern of ridges cover most of the skull roof, especially evident on the tip of the snout, as well as all over the parietals and the postparietals. Ridges and anteroposteriorly elongated ornamentation are evident in the posteromedial region of the snout, covering most of the frontals and part of the nasals and prefrontals. This elongated ornamentation is associated with intensive growth of the skull (Bystrow, 1935). The same kind of ridgeelongated sculpture is evident in the postorbital regions, covering most of the squamosals and part of the postorbitals, the jugals, and the quadratojugals. 

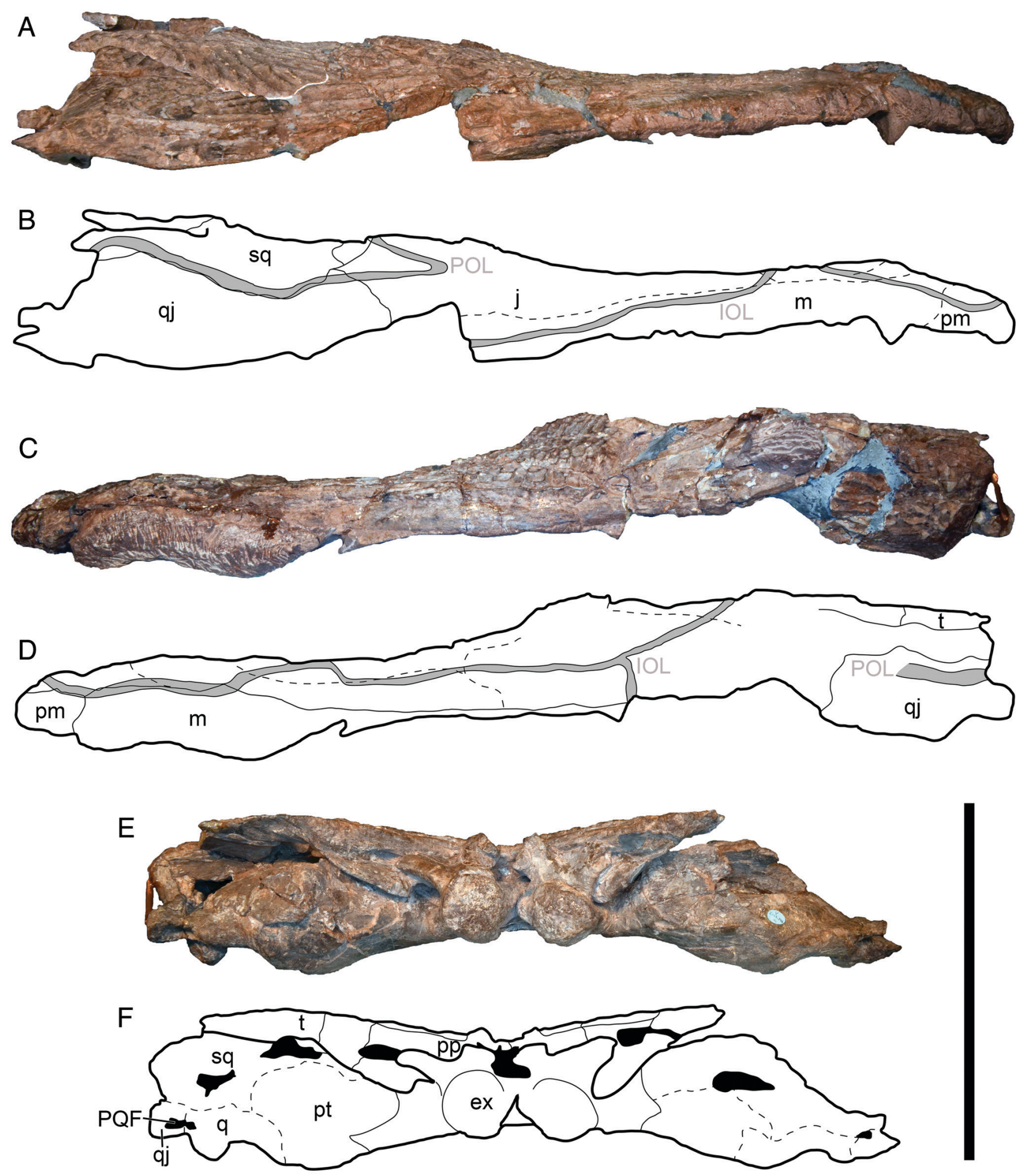

FIGURE 5. The holotype specimen of Cyclotosaurus naraserluki, MGUH.VP 9522. A, B, photograph and interpretative drawing of right lateral view; $\mathbf{C}, \mathbf{D}$, photograph and interpretative drawing of left lateral view; E, F, photograph and interpretative drawing of occipital view. Scale bar equals $20 \mathrm{~cm}$. 


\section{Lateral Line Sulci}

The lateral line sulci in $C$. naraserluki are present as pairs of supraorbital, infraorbital, and postorbital sulci. They are more evident laterally, especially in the posterior part of the skull, and weakly impressed medially, especially across the snout.

Supraorbital Sulci-The supraorbital sulci originate on the anterior part of the snout, medially to the nares. They meander anteroposteriorly from the nasals to the prefrontals, reaching the posterior part of the frontals, and weakly ending on the postfrontals, at around the midline of the orbits. Regardless of the weak preservation of both lacrimals, the left supraorbital sulcus seems to run along the suture between the prefrontal and the lacrimal, like in other cyclotosaurids and temnospondyls (see Schoch, 2008; Rinehart et al., 2015; Rinehart and Lucas, 2016; Witzmann et al., 2016).

Infraorbital Sulci-The infraorbital sulci originate lateral to the nares, first meandering anteroposteriorly on the maxillae, then curving with an acute flexure onto the lacrimals, ending atop or parallel to the jugal-maxilla sutures.

Postorbital Sulci-The postorbital sulci originate from the postorbital rim of the orbits. They run with a 'S'-shaped curvature onto the jugals and the quadratojugals at first, then along the squamosal-quadratojugal sutures, ending at the posterior margin of the skull.

\section{Skull Roof}

Teeth-Complete and incomplete labyrinthodont teeth are visible ventrally, protruding both from the vomers and the palatines as tusks, anteriorly to the palatal vacuities. These tusks have a conical shape and a circular cross-section. The vomers also bear six small teeth medially located posterior to the anterior palatal vacuity. Tooth alveoli are seen along the maxillae, the palatines, and the ectopterygoids, organized in rows.

Premaxillae-The premaxillae form the anterior-most rim of the snout and contact medially. In dorsal view, they contact the nasals posteriorly, the maxillae laterally, and form part of the nares rims. In ventral view, the premaxillae contact the maxillae laterally, the vomers posteriorly, and form the anterior half of the rim of the anterior palatal vacuity. The premaxillae bear the two premaxillary foramina for the accommodation of the mandibular tusks.

Maxillae-The maxillae form the major part of the lateral skull margin, extending from the anterior part of the nares to the midlength of the skull, up to the anterior margin of the orbits. Dorsally, they contribute to the lateral rim of the nares. The maxillae are bordered anteriorly by the premaxillae and medially by the nasals, the lacrimals, and the jugals. Ventrally, they contact the premaxillae anteromedially, the vomers and the palatines medially. They contribute to the anterolateral rim of the choanae.

Nasals-The nasals form most of the anterior part of the snout. Subrectangular in shape, they pair medially and contact the premaxillae anteriorly. Posteriorly, they taper to a triple point with the frontals posteromedially and the prefrontals posterolaterally. Laterally, the nasals contact first the maxillae behind the nares, then the lacrimals. Anterolaterally, they contribute to the narial rims.

Lacrimals - The lacrimal sutures are very faint. The right lacrimal seems to have a drop shape, with a wider parabolic posterior suture, where it contacts the prefrontal medially and the jugal laterally, and a more tapered anterior suture, where it is bordered by the nasal medially and the maxilla laterally. Ventrally, there are no visible sutures between the lacrimals and the bordering bones.

Jugals-The jugals form most of the cheek regions. Their total contribution to the length of the snout cannot be clearly delineated due to the weak preservation of the anterior sutures. Anteriorly, they taper at the contact with the lacrimal-maxilla suture, although this suture is faintly visible only on the right jugal. Medially, the jugal-maxilla suture runs anteroposteriorly. Laterally, the jugals are bordered by the prefrontals anterior to the orbits and by the postorbitals posterior to the orbits. The postorbital-jugal suture runs with a ' $Z$ '-shaped outline until reaching a triple point, where the jugals are bordered by the squamosals medially and the quadratojugals laterally. The jugals contribute to form a small part of the orbital rim.

Prefrontals-The prefrontals are two elongated bones that narrow anteriorly to a three-point suture with the nasals anteromedially and the lacrimals anterolaterally. Almost as long as the nasals and the frontals, they contact the former medioanteriorly and the latter medioposteriorly. Laterally, the jugals contact anteriorly the lacrimals and laterally the jugals; posteriorly, they form the anteriormost rim of the orbits.

Frontals-The frontals contact along the midline from the medial part of the snout until reaching the posterior level of the orbits. With a subtriangular anterior outline, they are bounded by the nasals anteriorly, forming a straight suture. The frontalprefrontal sutures run laterally, first with a straight course, then with a sigmoid curvature. Posteriorly, the frontals present a 'W'shaped suture, defined by the parietals posteromedially and by the postfrontals posterolaterally. The frontals contribute to a narrow portion of the orbital rim, projecting between the prefrontals and the postorbitals.

Postfrontals - The postfrontals have a subcircular shape and contribute to the posteromedial rim of the orbits. Anteriorly, they contact the frontals and are bordered by the parietals posteromedially, the supratemporals posteriorly, and the postorbitals laterally.

Postorbitals - The postorbitals have a subtrapezoidal shape and contribute to the posterolateral rim of the orbits. Medially, they contact the postfrontals and embay into the supratemporals posteromedially, projecting more laterally than the orbits. The postorbitals contact the jugals and the squamosals laterally.

Quadratojugals-The quadratojugals form the posterior-most side of the cheeks and the lateral-most part of the skull. In dorsal view, they have a subrectangular shape and contact the jugals anteriorly and the squamosals medially, along a sigmoidal suture. In ventral view, they contact the insulae jugalis anteriorly and the quadrates medially. They form a big part of the lateral and posterior rims of the adductor fossae. In occipital view, the quadratojugals contact the quadrates medially and the squamosals dorsally. In posterior view, the general aspect of the C. naraserluki skull appears to be rounded, with a slight deformation to the right side, probably due to taphonomy.

Parietals-The parietals contact medially, and they form a heart-shaped outline, with the tip facing anteriorly. They enclose the parietal foramen posteriorly to the midlength of their medial suture. They contact the frontals anteriorly, the postfrontals and the supratemporals laterally, and the postparietals posteriorly.

Supratemporals-The supratemporals present an arcuate shape, with the concavity projecting posteromedially. Anteriorly, the supratemporals embay the postorbitals and slightly contact with the postfrontals. The supratemporals contact the parietals medioanteriorly, by a straight suture, and the postparietals medioposteriorly, by an anterolaterally concave suture. The posteromedial supratemporal suture is a gentle curve contacting the squamosals and the tabulars.

Squamosals - The squamosals form a small part of the posterior rim of the skull, projecting between the quadratojugals and the tabulars. They contact the postorbitals and the jugals anteriorly, the supratemporals and the tabulars medially, and the quadratojugals laterally. The tabular-squamosal suture is fully visible in the left side of the skull, where it runs posterolaterally. The squamosals contribute to form about half of the otic fenestra rims. 
Postparietals - The postparietals contact along the posteriormost part of the midline and form the posterior concavity of the dorsal rim of the skull. Different from the rest of the midline, the contact between the two postparietals is not straight but follows a zig-zag course. The postparietal-parietal sutures extend mediolaterally, whereas the lateral contact with the supratemporals and the tabulars curves with a lateral concavity.

Tabulars-The polygonal shape of the tabulars broadens anteriorly and ends along the posterior, slightly convex margin of the skull. They contact the supratemporals anteriorly, the postparietals medially, and the squamosals laterally along a suture that embays the otic fenestra. The suture between the tabular and the squamosal is only appreciable posteriorly to the left otic fenestra. In dorsal view, the tabular horns project laterally. Also, they are the posterior-most projecting bones of the skull.

\section{Endocranium}

Quadrates-Ventrally, the quadrates present a polygonal shape that contacts the pterygoids medially and the quadratojugals laterally. The sutures of the quadrates are not clearly exposed or preserved. Anteriorly, the quadrates form part of the posterior rim of the adductor fossae, whereas posteriorly they contribute to the posterior margin of the skull.

Exoccipitals-The exoccipitals contact ventromedially and suture with the parasphenoid anteriorly. They project posteriorly to form the articulation with the atlas and diverge dorsally to enclose the ventral part of the foramen magnum. The posterior projection of the exoccipitals falls at the same level as the posterior-most projection of the quadrates. The posterior contact surfaces of the exoccipitals with the atlas are suboval in shape and flat.

\section{Palate}

Vomers-Anteriorly, the vomers form the posterior rim of the anterior palatal vacuity. Immediately behind this opening, six teeth are borne by the vomers, two by the left vomer and four by the right one, all set in a transverse row. The vomers also bear the first couple of palatal tusks. Anterolaterally, the vomers contact the premaxillae and the maxillae. Laterally, the vomers only contact the palatines and contribute to part of the choanae and to most of the medial rim of the palatal vacuities. The left vomer has a small posterolateral projection into the palatine. In ventral view, the vomers contact anteriorly, forming the posterior rim of the anterior palatal vacuity and the posterior part of the premaxillary-vomerine subdivision. Along the midline, the vomers contact one another except for the enclosure of the cultriform process of the parasphenoid. At their contact along the palatal vacuities, the vomers form a ' $\mathrm{V}$ '-shaped ridge that projects ventrally. The posterior contact between the vomers and the parasphenoid is weak.

Palatines-The palatines have a subrectangular shape and bear the second pair of palatal tusks. The right palatine also bears the third palatal tusk, which is not preserved on the left counterpart. Anteriorly, the palatines form the posterior rim of the choanae and contact the maxillae. The palatine-maxilla sutures run posterolaterally from the choanae to the ectopterygoid. Medially, the palatines contribute to the rim of the palatal vacuities. The posterior contact between the palatines and both the pterygoids and the ectopterygoids are indistinct.

Pterygoids - The pterygoids have a sinusoidal shape, extending between the palatal vacuities and the adductor fenestrae and forming part of their respective rims. Anteriorly, the pterygoids contact the palatines. Medially, the sutures that separate the pterygoids from the ectopterygoids and the insulae jugalis are poorly preserved to indistinguishable, except for the left pterygoid-insula jugalis suture. Posteriorly to the adductor fossae, the pterygoids contact the quadrates and form part of the posterior margin of the skull. The medial contact between the pterygoids and the parasphenoid is weakly noticeable. The right pterygoid bears a weak ornamentation anterior to the adductor fossa rim.

Parasphenoid-The parasphenoid is an unpaired, midline bone. Anteriorly, the cultriform process of the parasphenoid extends beyond the anterior margin of the palatal vacuities, enclosed by the vomers. The cultriform process projects ventrally, forming a keel-like structure that narrows posteriorly. The parasphenoid-exoccipital suture has a flat and long ' $M$ ' shape. The crista muscularis of the parasphenoid is an unpaired structure running transversely. Laterally, the parasphenoid contacts the pterygoids, although the sutures are barely visible. Nonetheless, it looks like the parasphenoid-pterygoid sutures are as long as the width of the parasphenoid basal plate. The left parasphenoid-pterygoid suture is the best preserved and ends at the posterior embayment of the skull margin, avoiding the contact between the pterygoids and the exoccipitals, a primitive condition shared with Rhinesuchidae, Eryosuchus Ochev, 1966, and Kupferzellia. The parasphenoid contributes to the posteromedial rim of the palatal vacuities and presents a left anterior protuberance, probably due to taphonomic deformation.

Ectopterygoids-The ectopterygoids are not easily observed in the palate of $C$. naraserluki because they are not completely prepared. Nonetheless, the left ectopterygoid preserves a somewhat distinct medial suture with the pterygoid and a posterior suture with the insula jugalis. The right ectopterygoid bears at least three distinct alveoli organized in a row, whereas the left ectopterygoid bears at least 12 distinct alveoli organized in an anteroposteriorly oriented row.

Insulae Jugalis - The insulae jugalis are weakly preserved. The right insula jugalis is nearly indistinguishable, whereas the left insula jugalis presents a trapezoid shape. It bounds the ectopterygoid anteriorly, the pterygoid medially, the quadratojugal laterally, and posteriorly it forms the anterior-most margin of the adductor fossa.

\section{Skull Openings}

Nares-The nares are two oval dorsal openings in the anterior part of the snout, with a maximum width of $3.5 \mathrm{~cm}$. They are bounded by the premaxillae, the maxillae, and the nasals.

Premaxillary Foramina-The $C$. naraserluki skull bears two premaxillary foramina for the reception of the mandibular tusks (Fig. 4). These two circular openings are filled with grayish sediment and noticeable on the dorsal surface of the skull, where they are enclosed completely by the premaxillae. Dorsally, the premaxillary foramina are evident in the anterior palatal vacuity.

Orbits-The orbits are the major openings of the dorsal side of the skull, with a maximum width of $5.5 \mathrm{~cm}$ and a subcircular outline. They are rimmed by the prefrontals, the frontals, the postfrontals, the jugals, and the postorbitals. The dorsal margin of the orbits is level with the rest of the skull roof.

Parietal Foramen-The parietal foramen is the smallest of the skull openings and the only unpaired one. Its maximum width is $1.1 \mathrm{~cm}$, and it is completely enclosed by the parietals.

Otic Fenestrae - The otic fenestrae characterize the posterior skull roof and are bounded by the squamosals and the tabulars. The left otic fenestra is an oval cavity, elongated anteroposteriorly, with a maximum width of $4.5 \mathrm{~cm}$. The right otic fenestra is posteriorly open due to the missing portion of the posterior contact between the squamosal and the tabular.

Anterior Palatal Vacuity - The anterior palatal vacuity is an ' $U$ '-shaped depression with a maximum length of $4.9 \mathrm{~cm}$ and width of $11.3 \mathrm{~cm}$. It is enclosed by the premaxillae and the vomers. The anterior palatal vacuity presents the premaxillary foramina, two subcircular openings filled with sediment.

Choanae-The choanae are two circular cavities in the anterior part of the palate with a maximum width of $4.4 \mathrm{~cm}$. Only the 

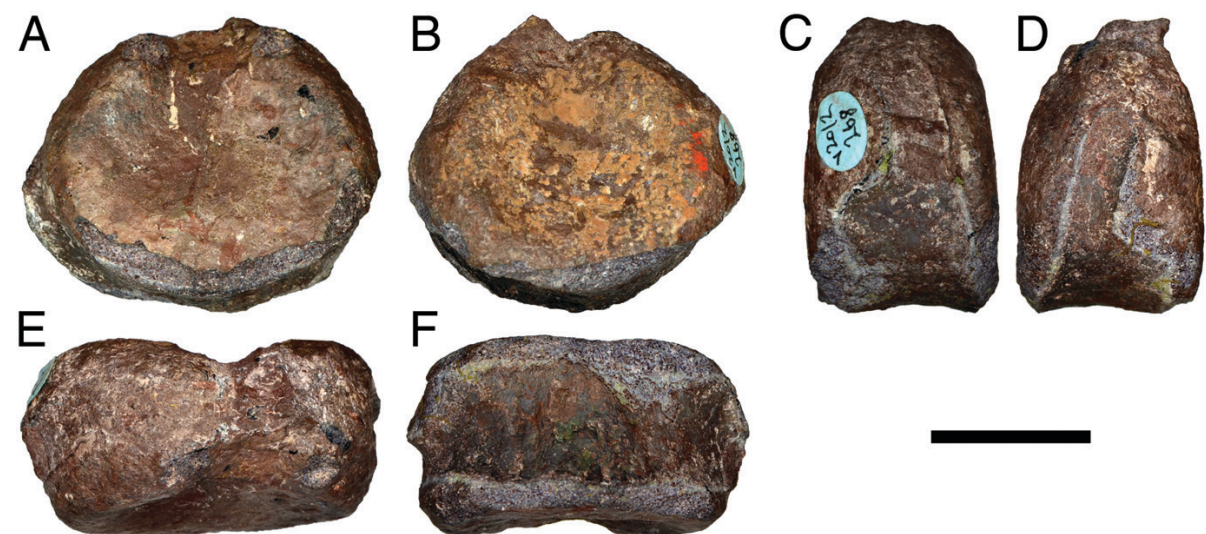

$\mathrm{F}$
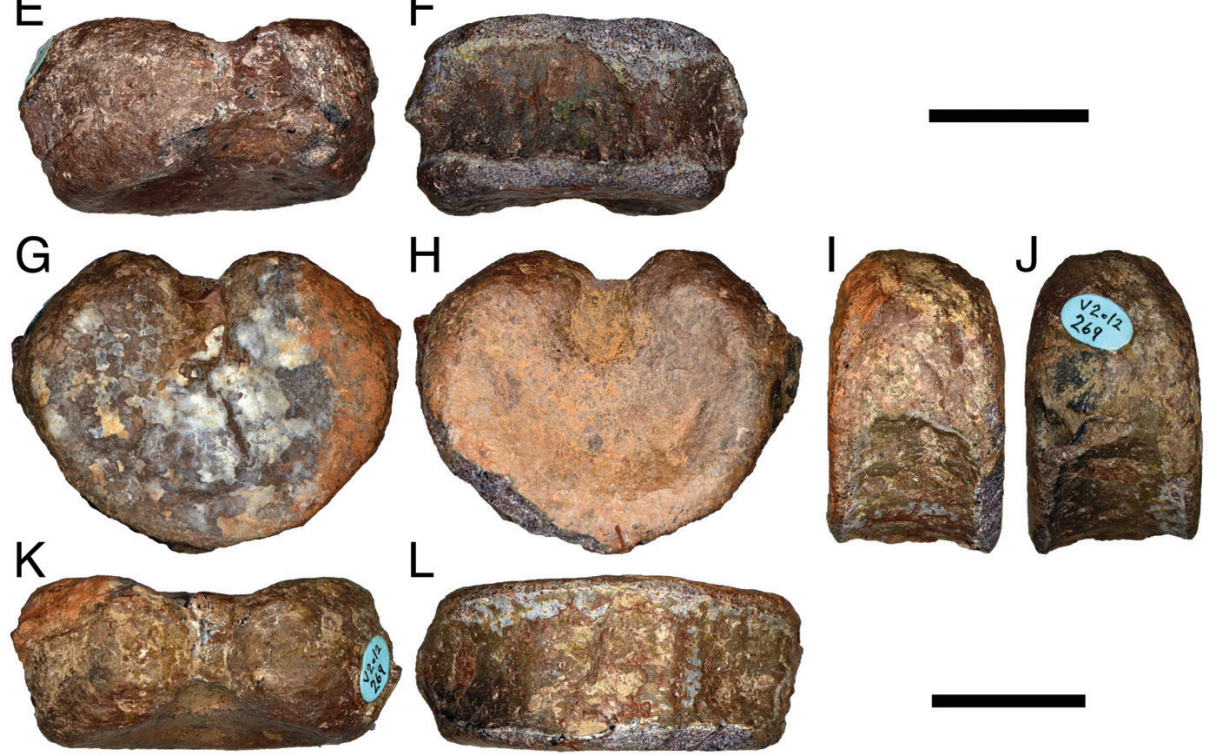

FIGURE 6. MGUH.VP $9523(\mathbf{A}-\mathbf{F})$ and MGUH.VP 9524 (G-L), vertebral intercentra associated with Cyclotosaurus naraserluki. $\mathbf{A}, \mathbf{G}$, anterior view; $\mathbf{B}, \mathbf{H}$, posterior view; $\mathbf{C}$, $\mathbf{I}$, right lateral view; $\mathbf{D}, \mathbf{J}$, left lateral view; $\mathbf{E}$, $\mathbf{K}$, dorsal view; $\mathbf{F}, \mathbf{L}$, ventral view. The visible labels on specimens refer to a former labeling system. Scale bars equal $2 \mathrm{~cm}$. left choana preserves its original shape, whereas the right choana is deformed.

Palatal Vacuities - The palatal vacuities are the biggest openings of the palate, with a ' $D$ '-shaped outline, a maximum length of $28.9 \mathrm{~cm}$, and a maximum width of $10.9 \mathrm{~cm}$. The marginal rims are almost straight, whereas laterally they present a parabolic curvature with the posterior curvature more acute than the anterior one. The palatal vacuities are enclosed by the vomers, the palatines, the pterygoids, and the parasphenoid.

Adductor Fossae-The adductor fossae characterize the posterior-most region of the palate. The left adductor fossa is the best preserved and presents an arch shape with a gentle lateral convexity and a more acute medial concavity. The maximum length measured parallel to the midline is $16.9 \mathrm{~cm}$, and the maximum width is $10.4 \mathrm{~cm}$.

\section{Postcranial Skeleton}

Vertebrae-Two amphicoelic intercentra represent the only preserved postcranial elements of $C$. naraserluki (Fig. 6). They display a convex ventral surface, with a ventral thickness of $21 \mathrm{~mm}$ in MGUH.VP 9523 and $22 \mathrm{~mm}$ in MGUH.VP 9524. Dorsally, they are characterized by a central dorsoventral depression that also compresses the two intercentra anteroposteriorly down to $11 \mathrm{~mm}$ in thickness for MGUH.VP 9523 and down to $13 \mathrm{~mm}$ for MGUH.VP 9524. In MGUH.VP 9523 the maximum width is $42 \mathrm{~mm}$ and the maximum height is $25 \mathrm{~mm}$, whereas MGUH.VP 9524 has a maximum width of $48 \mathrm{~mm}$ and height of $37 \mathrm{~mm}$. Among other capitosauroids, these kinds of intercentra have so far only been reported from Mastodonsaurus Jaeger, 1828, and Cyclotosaurus hemprichi (Kuhn, 1942; Schoch, 1999). Intercentra of similar size and morphology have been further described by Milner et al. (1996) from the Norian of Luxemburg and the ?Carnian-Norian of Algarve in Portugal (Witzmann and
Gassner, 2008), the latter associated to stereospondyls, such as Mastodonsaurus and Cyclotosaurus. However, the material from Portugal is questionable: new well-documented discoveries from the Algarve (Steyer et al., 2011; Brusatte et al., 2015) show the presence of Metoposaurus algarvensis Brusatte et al., 2015, which may suggest a need to reassess the identification of the previous fragmentary material (Witzmann and Gassner, 2008).

\section{PHYLOGENETIC RESULTS}

The phylogenetic analysis yielded one most parsimonious tree (Figs. 7, 8), with a tree length (TL) of 109 steps and consistency index (CI) of 0.624, retention index (RI) of 0.680, and rescaled consistency index (RCI) of 0.424 . Because of the recoding of character 7 and the addition of $C$. naraserluki, our phylogeny of Cyclotosaurus is slightly different from the one presented in Witzmann et al. (2016). Cyclotosaurus loses one synapomorphy (char. 48-1, quadrate ramus of the pterygoid laterally aligned and abbreviated) and the synapomorphy based on character 7 passes from state 0, 'lateral line sulci weakly impressed, discontinuous,' to state 2, 'lateral line sulci well impressed laterally but weakly impressed or discontinuous medially.' In general, most of the groups within Capitosauroidea (sensu Schoch, 2008) are poorly supported, with the exception of the genus Mastodonsaurus and the Heylerosauridae (sensu Schoch, 2008), which includes Eocyclotosaurus Ortlam, 1970, and Quasicyclotosaurus. Moreover, despite presenting seven synapomorphies, the genus Cyclotosaurus is not well supported and may easily collapse due to the numerous reversals. New data and characters may help to overturn and increase the precision of the relations between these species.

Cyclotosaurus robustus remains the most basal Cyclotosaurus taxon, a position supported by a cultriform process that forms a deltoid base (char. 52-1). The remaining Cyclotosaurus taxa 


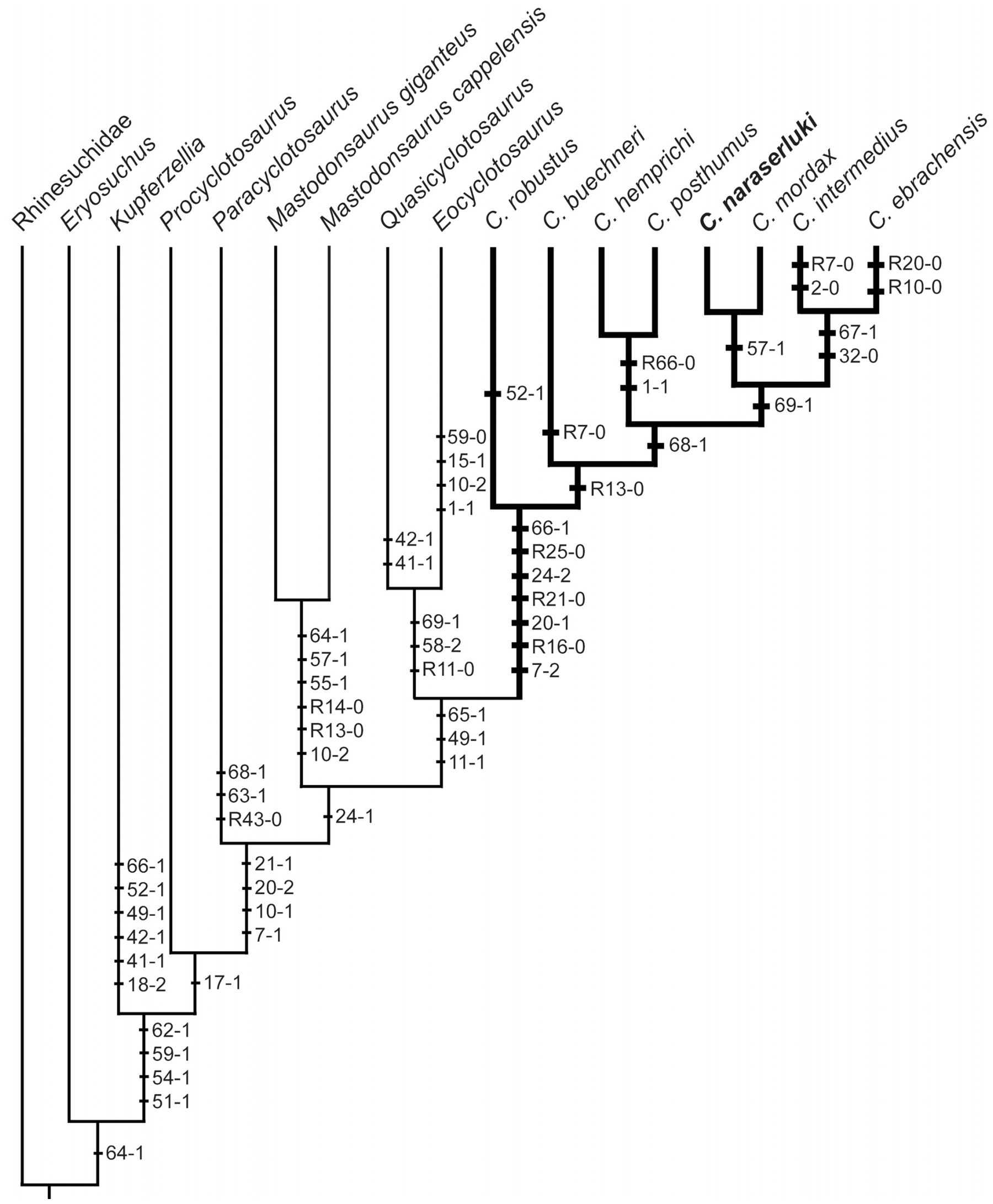

FIGURE 7. Most parsimonious tree of the Capitosauroidea (sensu Schoch, 2008) produced by a TNT 1.5 analysis (tree length $=109$ steps, consistency index $=0.624$, retention index $=0.680$, rescaled consistency index $=0.424$ ). Synapomorphies are shown along the tree and numbers refer to the characters listed in the phylogeny in Witzmann et al. (2016). Thicker branches represent the genus Cyclotosaurus in the analysis. Abbreviations: $\boldsymbol{C}$., Cyclotosaurus; $\mathbf{R}$, reversal. 


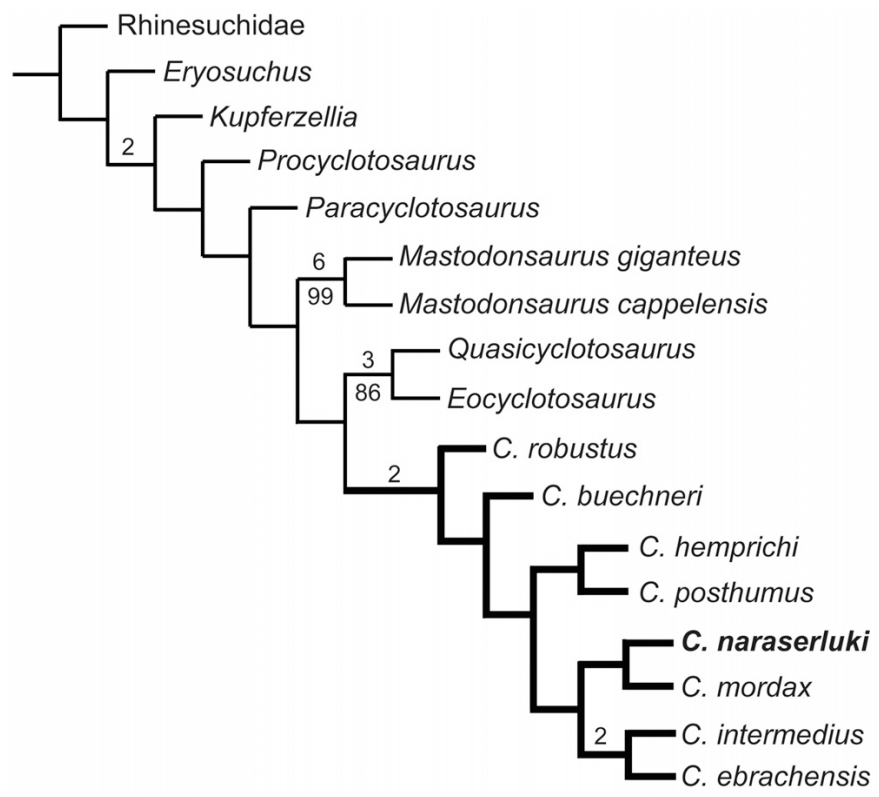

FIGURE 8. Most parsimonious tree presented in Figure 7 showing Bremer support values (number over the branches) $>1$ and bootstrap values (numbers under the branches) after 1000 replicates.

possess a preorbital projection of the jugals shorter than half of the snout length (reversal for char. 13-0). Cyclotosaurus buechneri presents lateral line sulci weakly impressed and discontinuous (reversal for char. 7-0). All post- $C$. buechneri cyclotosaurs have an interorbital width to width of the orbits ratio equal to or greater than 1.8 (char. 68-1). Cyclotosaurus hemprichi and $C$. posthumus are sister taxa, a relationship supported by a tapered preorbital region (char. 1-1) and an elongated parabolic snout (reversal for char. 66-0). A straight-to-convex posteromedial margin of the tabulars (char.69-1) is synapomorphic for the remaining four species of Cyclotosaurus, which branch into two clades. The clade formed by $C$. naraserluki and C. mordax is supported by a snout bearing a pair of premaxillary foramina to accommodate mandibular tusks (char. 57-1). The second clade includes $C$. intermedius and $C$. ebrachensis. It is supported by the presence of palatal denticle fields borne on the parasphenoid and/or the pterygoid (char. 32-0) and straight postorbital lateral margins of the skull (char. 67-1). Cyclotosaurus intermedius is supported by having the quadrates projecting posteriorly to the distal ends of the tabular horns (char. 2-0) and a weakly and discontinuous impression of the lateral sulci (reversal for char. 7-0). Cyclotosaurus ebrachensis is supported by supraorbital sulci passing over the nasals (reversal for char. 10-0) and by an unpaired anterior palatal vacuity (reversal for char. 20-0).

\section{DISCUSSION}

\section{Paleoecology and Paleogeography}

The remains here described belong to a new species of Cyclotosaurus, namely, C. naraserluki, sp. nov., the largest amphibian reported from Greenland heretofore (Jenkins et al., 1994, 2008). Cyclotosaurus naraserluki shared its living habitat with other semiaquatic amphibians and reptilian predators, such as Gerrothorax pulcherrimus (Jenkins et al., 2008) and phytosaurs (Mateus et al., 2014; Clemmensen et al., 2016; Marzola et al., 2016). The co-occurrence of Cyclotosaurus with other predators in the same area is consistent among all the known Late Triassic faunal associations from Europe where Cyclotosaurus has been reported (i.e., Sulej and Majer, 2005; Witzmann and Gassner,
2008). In the Greenland scenario, this may be explainable by different predatory habits, strategies, and physiological capacities of different taxa over the coasts of a huge seasonal lake in the Jameson Land Basin: large phytosaurs were actively preying on large terrestrial vertebrates and fish, like modern crocodiles; Cyclotosaurus and Gerrothorax were probably sharing ecological niches, but with the former being larger in size and preying mostly on fish, and the latter feeding on small fish, larvae, and invertebrates.

The Late Triassic Greenland fauna shows more affinities to European occurrences (dominated by genera such as Cyclotosaurus, Gerrothorax Nilsson, 1934, Mastodonsaurus, Metoposaurus Lydekker, 1890, and Procyclotosaurus Watson, 1958) than to North American ones. In the Late Triassic, there is a clear distinction between the European-Greenlandic and the North American faunas, with the unique presence in the latter of $A p a-$ chesaurus Hunt, 1993, Eocyclotosaurus, Koskinonodon Branson and Mehl, 1929, Paracyclotosaurus, and Quasicyclotosaurus (Watson, 1958; Jenkins et al., 1994, 2008; Schoch, 1999, 2000; Sulej, 2002; Brusatte et al., 2015; Kear et al., 2016; Rinehart et al., 2015; Rinehart and Lucas, 2016).

Greenland is, and always has been, part of the North American continent, and despite the early opening of the North Atlantic, the Triassic fauna and flora show more affinities to the one in central Europe. This may be explained by several factors: (1) the equivalent paleolatitude of Greenland and central Europe promoted similar faunas, in contrast to the subequatorial paleolatitudinal position of known North American fossil occurrences in Texas, New Mexico, and Arizona; (2) at that time, the geographical distance between Greenland and central Europe was shorter than to southern North America, which may have facilitated dispersal; and (3) the deserts and arid regions separating Greenland and Texas, New Mexico, and Arizona may have been a much more efficient barrier to the temnospondyls than the proto-Atlantic between Greenland and Europe. Some tolerance for salinity may have given a dispersal advantage to capitosauroids.

\section{CONCLUSIONS}

Cyclotosaurus naraserluki is the largest amphibian ever reported from Greenland. It possesses several autapomorphies that distinguish it from its sister taxon, C. mordax, within the genus Cyclotosaurus.

The record of Cyclotosaurus from the Fleming Fjord Formation in East Greenland, together with Gerrothorax pulcherrimus, shows a close correlation between the Greenlandic Late Triassic amphibian fauna and the amphibian fauna of the coeval European basins, such as Germany, Poland, and Portugal.

The temnospondyl faunas of Europe and the Scandinavian Arctic (Greenland and Svalbard archipelagos) are characterized by taxa not found in coeval temnospondyl faunas from North America, showing a geographical connection between East Greenland and central Europe despite the opening of the North Atlantic.

The geographic position of Greenland and the Jameson Land Basin during the Late Triassic makes $C$. naraserluki one of the amphibians known to have lived at the highest paleolatitude, sharing trophic habitats with other amphibian and reptilian predators.

\section{ACKNOWLEDGMENTS}

We thank K. M. Gregersen (MGUH) and N. Natorp (GCMK) for access to the material. We are also thankful to $\mathrm{M}$. MorenoAzanza (Universidade NOVA de Lisboa/Museu da Lourinhã) for invaluable help and discussion on the phylogeny; A. Luz (Museu da Lourinhã) for the artwork of the skull; O. Rauhut (BSPG/Ludwig Maximilian University) for kindly providing 
photos of the holotype of Cyclotosaurus ebrachensis; and R. Schoch (SMNS) and F. Witzmann (MB) for useful discussion on cyclotosaur phylogeny and character identification. Finally, we are thankful to T. Sulej (ZPAL), J. Fröbisch (MB), and an anonymous reviewer for useful reviews and for helping to significantly improve the original manuscript.

M.M. is supported by the Fundação para a Ciência e a Tecnologia doctoral fellowship SFRH/BD/99580/2014 (Ministério da Ciência, Tecnologia e Ensino superior, Portugal). M.M. was also supported in visiting museum collections by the 2015 European Association of Vertebrate Palaeontologists Research Grant (EAVP-ERG) and by the 2015 Stan Wood Award of The Palaeontological Association (PA-SW201502). Field work in Greenland by L.B.C. was supported by the Carlsberg Foundation.

\section{ORCID}

\section{Marco Marzola (D) http://orcid.org/0000-0002-7067-2502}

Octávio Mateus (iD http://orcid.org/0000-0003-1253-3616

Lars B. Clemmensen (iD) http://orcid.org/0000-0002-3265-9307

\section{LITERATURE CITED}

Andrews, S. D., S. R. Kelly, W. Braham, and M. Kaye. 2014. Climatic and eustatic controls on the development of a Late Triassic source rock in the Jameson Land Basin, East Greenland. Journal of the Geological Society 171:609-619.

Bertinelli, A., M. Casacci, G. Concheri, G. Gattolin, L. Godfrey, M. E. Katz, M. Maron, M. Mazza, P. Mietto, G. Muttoni, M. Rigo, M. Sprovieri, F. Stellin, and M. Zaffani. 2016. The Norian/Rhaetian boundary interval at Pignola-Abriola section (Southern Apennines, Italy) as a GSSP candidate for the Rhaetian Stage: an update. Albertiana 43:5-18.

Branson, E. B., and M. G. Mehl. 1929. Triassic amphibians from the Rocky Mountain region. University of Missouri Studies 4:155-239.

Brusatte, S. L., R. J. Butler, O. Mateus, and J. S. Steyer. 2015. A new species of Metoposaurus from the Late Triassic of Portugal and comments on the systematics and biogeography of metoposaurid temnospondyls. Journal of Vertebrate Paleontology. doi: 10.1080/ 02724634.2014.912988.

Bystrow, A. P. 1935. Morphologische Untersuchungen der Deckknochen Desschädels der Wirbeltiere. Acta Zoologica 16:65-141.

Clemmensen, L. B. 1980a. Triassic rift sedimentation and palaeogeography of central East Greenland. Grønlands Geologiske Undersøgelse Bulletin 136:1-72.

Clemmensen, L. B. 1980b. Triassic lithostratigraphy of East Greenland between Scoresby Sund and Kejser Franz Josephs Fjord. Grønlands Geologiske Undersøgelse Bulletin 139:1-56.

Clemmensen, L. B., D. V. Kent, and F. A. Jenkins. 1998. A Late Triassic lake system in East Greenland: facies, depositional cycles and palaeoclimate. Palaeogeography, Palaeoclimatology, Palaeoecology 140:135-159.

Clemmensen, L. B., J. Milàn, J. S. Adolfssen, E. J. Estrup, N. Frobøse, N. Klein, O. Mateus, and O. Wings. 2016. The vertebrate-bearing Late Triassic Fleming Fjord Formation of central East Greenland revisited: stratigraphy, palaeoclimate and new palaeontological data. Geological Society, London, Special Publications 434(1), 31-47.

Cohen, K. M., S. C. Finney, P. L. Gibbard, and J.-X. Fan. 2013. The ICS international chronostratigraphic chart. Episodes 36:199-204.

Damiani, R. J. 2001. A systematic revision and phylogenetic analysis of Triassic mastodonsauroids (Temnospondyli: Stereospondyli). Zoological Journal of the Linnean Society 133:379-482.

Fortuny, J., J. Marcé-Nogué, J.-S. Steyer, S. de Esteban-Trivigno, E. Mujal, and L. Gil. 2016. Comparative 3D analyses and palaeoecology of giant early amphibians (Temnospondyli: Stereospondyli). Scientific Reports 6:30387.

Fraas, E. 1889. Die Labyrinthodonten der schwäbischen Trias. Palaeontographica 36:1-158.

Fraas, E. 1913. Neue Labyrinthodonten aus der schwäbischen Trias. Palaeontographica 60:275-294.

Goloboff, P. A., and S. A. Catalano. 2016. TNT version 1.5, including a full implementation of phylogenetic morphometrics. Cladistics 32:221-238.
Hansen, B. B., J. Milàn, L. B. Clemmensen, J. S. Adolfssen, E. J. Estrup, N. Klein, O. Mateus, and O. Wings. 2016. Coprolites from the Late Triassic Kap Stewart Formation, Jameson Land, East Greenland: morphology, classification and prey inclusions. Geological Society, London, Special Publications 434:49-69.

Hunt, A. P. 1993. Revision of the Metoposauridae (Amphibia: Temnospondyli) and description of a new genus from western North America. Museum of Northern Arizona Bulletin 59:67-97.

Jaeger, G. F. 1828. Über die fossilen Reptilien, welche in Württemberg aufgefunden worden sind. Metzler, Stuttgart, $46 \mathrm{pp}$.

Jenkins, F. A., S. M. Gatesy, N. H. Shubin, and W. W. Amaral. 1997. Haramiyids and Triassic mammalian evolution. Nature 385:715-718.

Jenkins, F. A., N. H. Shubin, S. M. Gatesy, and K. Padian. 2001. A diminutive pterosaur (Pterosauria: Eudimorphodontidae) from the Greenlandic Triassic. Bulletin of the Museum of Comparative Zoology 156:151-170.

Jenkins, F. A., N. H. Shubin, S. M. Gatesy, and A. Warren. 2008. Gerrothorax pulcherrimus from the Upper Triassic Fleming Fjord Formation of East Greenland and a reassessment of head lifting in temnospondyl feeding. Journal of Vertebrate Paleontology 28:935950.

Jenkins, F. J., N. H. Shubin, W. W. Amarel, S. M. Gatesy, C. R. Schaff, L. B. Clemmensen, W. R. Downs, A. R. Davidson, N. C. Bonde, and F. Osbaeck. 1994. Late Triassic continental vertebrates and depositional environments of the Fleming Fjord Formation, Jameson Land, east Greenland. Meddelelser Om Grønland 32:1-25.

Kear, B. P., S. F. Poropat, and M. Bazzi. 2016. Late Triassic capitosaurian remains from Svalbard and the palaeobiogeographical context of Scandinavian Arctic temnospondyls. Geological Society, London, Special Publications 434(1), 1-11.

Kent, D. V., and L. B. Clemmensen. 1996. Paleomagnetism and cycle stratigraphy of the Triassic Fleming Fjord and Gipsdalen formations of East Greenland. Bulletin of the Geological Society of Denmark 42:121-136.

Kent, D. V., and P. E. Olsen. 1999. Astronomically tuned geomagnetic polarity timescale for the Late Triassic. Journal of Geophysical Research: Solid Earth 104(B6), 12831-12841.

Kent, D. V., and L. Tauxe. 2005. Corrected Late Triassic latitudes for continents adjacent to the North Atlantic. Science 307:240-244.

Kent, D. V., P. S. Malnis, C. E. Colombi, O. A. Alcober, and R. N. Martínez. 2014. Age constraints on the dispersal of dinosaurs in the Late Triassic from magnetochronology of the Los Colorados Formation (Argentina). Proceedings of the National Academy of Sciences of the United States of America 111:7958-7963.

Klein, H., J. Milàn, L. B. Clemmensen, N. Frobøse, O. Mateus, N. Klein, J. S. Adolfssen, E. J. Estrup, and O. Wings. 2016. Archosaur footprints (cf. Brachychirotherium) with unusual morphology from the Upper Triassic Fleming Fjord Formation (Norian-Rhaetian) of East Greenland. Geological Society, London, Special Publications 434(1), 71-85.

Kuhn, O. 1932. Labyrinthodonten und Parasuchier aus dem mittleren Keuper von Ebrach in Oberfranken. Neues Jahrbuch für Mineralogie, Geologie und Paläontologie, Abteilung B, Beilageband 69:94143.

Kuhn, O. 1942. Über Cyclotosaurus hemprichi Kuhn und einige weitere Tetrapodenreste aus dem Keuper von Halberstadt. Beiträge Zur Geologie von Thüringen 6:181-197.

Lydekker, R. 1890. Catalogue of the Fossil Reptilia and Amphibia in the British Museum of Natural History. Part IV. British Museum of Natural History, London, 295 pp.

Marzola, M., O. Mateus, O. Wings, N. Klein, J. Milàn, and B. L. Clemmensen. 2016. The herpetofauna from the Late Triassic of the Jameson Land Basin (East Greenland): review and updates; in Holwerda, F., A. Madern, D. Voeten, A. van Heteren, J. Liston, H. Meijer, and N. den Ouden, Programme and Abstract Book of the XIV Annual Meeting of the European Association of Vertebrate Paleontologists, Haarlem, The Netherlands. p. 177.

Mateus, O., L. B. Clemmensen, N. Klein, O. Wings, N. Frobøse, J. Milàn, J. Adolfssen, and E. Estrup. 2014. The Late Triassic of Jameson Land revisited: new vertebrate findings and first phytosaur from Greenland. Journal of Vertebrate Paleontology 34(Program and Abstracts): 182 .

Meyer, H. von, and T. H. Plieninger. 1844. Beiträge zur Paläontologie Württembergs, enthaltend die fossilen Wirbelthierreste aus den Triasgebilden mit besonderer Rücksicht auf die Labyrinthodonten des 
Keupers. E. Schweizerbart'sche Verlagsbuchhandlung, Stuttgart, $132 \mathrm{pp}$.

Milàn, J., L. B. Clemmensen, J. S. Adolfssen, E. J. Estrup, N. Frobøse, N. Klein, O. Mateus, and O. Wings. 2012. A preliminary report on coprolites from the Late Triassic part of the Kap Stewart Formation, Jameson Land, East Greenland. New Mexico Museum of Natural History and Science, Bulletin 57:203-206.

Milner, A. R. 1994. Late Triassic and Jurassic amphibians: fossil record and phylogeny; pp. 5-22 in N. C. Fraser and H.-D. Sues (eds.), In the Shadow of the Dinosaurs: Early Mesozoic Tetrapods. Cambridge University Press, New York.

Milner, A. R., C. Duffin, and D. Delsate. 1996. Plagiosaurid and capitosaurid amphibian material from the Late Triassic of Medernach, Grand-Duchy of Luxembourg: preliminary note: Jurassic-Triassic vertebrates. Bulletin de la Société Belge de Géologie 104:43-53.

Nilsson, T. 1934. Vorläufige Mitteilung über einen Stegocephalenfund aus dem Rhät Schonens. Geologiska Föreningens i Stockholm Förhandlingar 56:428-442.

Ochev, V. G. 1966. Systematics and Phylogeny of Capitosauroid Labyrinthodonts. Izdatel'stvo Saratovskogo Universiteta, Saratov, Russia, 184 pp. [Russian]

Ortlam, D. 1970. Eocyclotosaurus woschmidti n. g. n. sp. ein neuer Capitosauride aus dem Oberen Buntsandstein des nördlichen Schwarzwaldes. Neues Jahrbuch für Mineralogie, Geologie und Paläontologie, Abhandlungen 1970:558-568.

Paton, R. L. 1974. Capitosauroid labyrinthodonts from the Trias of England. Palaeontology 17:253-289.

Rinehart, L. F., and S. G. Lucas. 2016. Eocyclotosaurus appetolatus, a Middle Triassic Amphibian: Osteology, Life History, and Paleobiology. New Mexico Museum of Natural History Bulletin 70, 118 pp.

Rinehart, L. F., S. G. Lucas, and R. R. Schoch. 2015. Eocyclotosaurus appetolatus, a new cyclotosaurid amphibian from the Middle Triassic (Perovkan) Moenkopi Formation of New Mexico, USA. Journal of Vertebrate Paleontology. 10.1080/02724634.2014.929140.

Säve-Söderbergh, G. 1935. On the dermal bones of the head in labyrinthodont stegocephalians and primitive reptilia: with special reference to Eotriassic stegocephalians from East Greenland. Meddelelser om Grønland 98:1-211.

Schoch, R. R. 1997. A new capitosaur amphibian from the Lower Lettenkeuper (Triassic: Ladinian) of Kupferzell (Southern Germany) Neues Jahrbuch für Geologie und Paläontologie, Abhandlungen 203:239-272

Schoch, R. R. 1999. Comparative Osteology of Mastodonsaurus giganteus (Jaeger, 1828) from the Middle Triassic (Lettenkeuper: Longobardian) of Germany (Baden-Württemberg, Bayern, Thüringen). Stuttgarter Beiträge zur Naturkunde, Serie B (Geologie und Paläontologie) 278:1-175.

Schoch, R. R. 2000. The status and osteology of two new cyclotosaurid amphibians from the Upper Moenkopi Formation of Arizona (Amphibia: Temnospondyli; Middle Triassic). Neues Jahrbuch für
Mineralogie, Geologie und Paläontologie, Abhandlungen 216:387411.

Schoch, R. R. 2008. The Capitosauria (Amphibia): characters, phylogeny, and stratigraphy. Palaeodiversity 1:189-226.

Schoch, R. R., and A. R. Milner. 2000. Stereospondyli. Encyclopedia of Palaeoherpetology, Part 3B. Verlag Dr. Friedrich Pfeil, Munich, $203 \mathrm{pp}$

Shishkin, M. A. 1964. Suborder Stereospondyli; pp. 83-122 in Y. A. Orlov (ed.), Osnovy Paleontologii. Amphibia, Reptila, Aves. Moscow, Nauka, 722 pp. [Russian]

Steyer, J. S., O. Mateus, R. J. Butler, S. L. Brusatte, and J. H. Whiteside. 2011. A new metoposaurid (temnospondyl) bonebed from the Late Triassic of Portugal. Journal of Vertebrate Paleontology 31(Programs and Abstracts):200.

Sulej, T. 2002. Species discrimination of the Late Triassic temnospondyl amphibian Metoposaurus diagnosticus. Acta Palaeontologica Polonica 47:535-546.

Sulej, T., and D. Majer. 2005. The temnospondyl amphibian Cyclotosaurus from the Upper Triassic of Poland. Palaeontology 48:157-170.

Sulej, T., A. Wolniewicz, N. Bonde, B. Bażejowski, G. Niedźwiedzki, and M. Talanda. 2014. New perspectives on the Late Triassic vertebrates of East Greenland: preliminary results of a Polish-Danish palaeontological expedition. Polish Polar Research 35:541-552.

Watson, D. M. S. 1958. A new labyrinthodont (Paracyclotosaurus) from the Upper Trias of New South Wales. Bulletin of the British Museum of Natural History (Geology) 3:22-263.

Wepfer, E. 1923. Der Buntsandstein Des Badischen Schwarzwalds und Seine Labyrinthodonten. Monographien zur Geologie und Palaeontologie 1:1-101.

Witzmann, F., and T. Gassner. 2008. Metoposaurid and mastodonsaurid stereospondyls from the Triassic-Jurassic boundary of Portugal Alcheringa 32:37-51.

Witzmann, F., S. Sachs, and C. J. Nyhuis. 2016. A new species of Cyclotosaurus (Stereospondyli, Capitosauria) from the Late Triassic of Bielefeld, NW Germany, and the intrarelationships of the genus. Mitteilungen aus dem Museum für Naturkunde in Berlin. Fossil Record 19:83-100.

Wotzlaw, J.-F., J. Guex, A. Bartolini, Y. Gallet, L. Krystyn, C. A. McRoberts, D. Taylor, B. Schoene, and U. Schaltegger. 2014. Towards accurate numerical calibration of the Late Triassic: high-precision $\mathrm{U}-\mathrm{Pb}$ geochronology constraints on the duration of the Rhaetian Geology 42:571-574.

Zittel, K. A. von. 1890. Handbuch der Palaeontologie. 1. Abtheilung: Palaeozoologie. 3rd vol. Vertebrata (Pisces, Amphibia, Reptilia, Aves). Oldenbourg, Munich, 900 pp.

Submitted August 4, 2016; revisions received December 15, 2016; accepted January 19, 2017.

Handling editor: Jörg Fröbisch.

APPENDIX 1. Character coding scores for the 69 characters of Witzmann et al. (2016).

Cyclotosaurus naraserluki

$010100220[0,1] 11 ? 1001201010201110 ? 1110 ? 11111$ ????? ??111 ?0?20 $01011190 ? 01011$ 